\title{
STATISTICAL VIEW TO DEVELOPMENT LITHUANIA: PROSPECTS OF COMPETITIVENESS IN THE ENLARGED EUROPEAN UNION
}

\author{
Romualdas Ginevičius \\ Vilnius Gediminas Technical University, Saulètekio al. 11, LT-10223 Vilnius, Lithuania \\ E-mail: rector@adm.vtu.lt
}

Received 3 November 2004; accepted 10 December 2004

\begin{abstract}
The aim of the paper is to present a statistical view to Lithuanian development tendencies and to highlight specific features of country's economic structure. Statistical approach grounded on theoretical elaborations of consistent patterns of transition countries' development should lead to concretization of state economic policy in field of defining of development directions.
\end{abstract}

Keywords: Lithuanian economy, industry, services, agriculture, foreign trade, foreign direct investments

\section{Introduction}

Acceleration of growth of transition economies, which are considerably lagging behind developed ones in terms of GDP per capita, is a topical issue having being tackled continuously. Rates of development of distorted by centrally planned economies depend on two major groups of factors. One group could be attributed to consistent patterns of development and condition some natural involuntary tendencies of modification of economy structure. Another group of factors, which determine economy structure and its changes, could be related with current comparative advantage of country and usage of it in foreign trade. The question we arise is as follows: what exactly comparative advantages Lithuania uses and, how prospective they are. To put it into other way, to formulate efficient state policy we need to evaluate if comparative advantages we use will enable us to maintain growth rates of economy we, as transition country, enjoy at current period.

\section{Lithuanian economical structure}

Let's take a closer look at Lithuania's case in terms of restructuring tendencies after it seceded from Soviet Union in 1990.

Structure of Lithuanian GDP indicates that services and industry are main sectors of economics. Despite agricultures share is declining it still remains comparatively high and, in Lithuanian case, plays extremely important role in economy (that we will discuss below).

Share of industry dropped significantly in year 1999, what is related with Russian crisis. Lithuania, being the mostly related to Russia in terms of export, suffered not only significant slowdown in economic growth, but also was forced to contract its share of industry.

All Baltic States, Lithuania, Latvia and Estonia experienced shock effect, but Lithuania having Russia as the most important trade partner, was the most vulnerable one. 

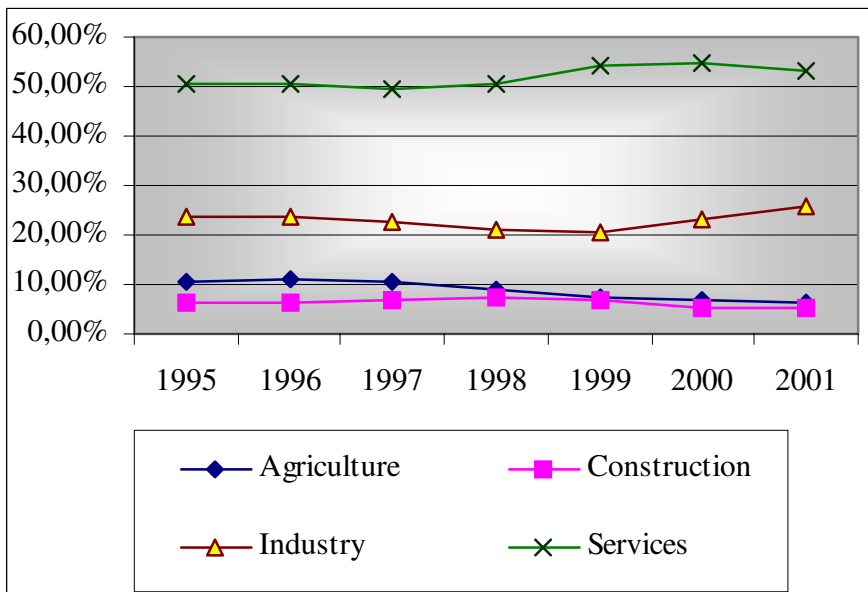

Chart 1. GDP structure in Lithuania by sectors (Department of Statistics of Lithuania http://www.std.lt

In order to determine future restructuring trends in the context of strength of Lithuanian comparative advantage let's examine the following factors: productivity of main sectors in relation with export structure.

Judging from Chart 2, presented above, Lithuanian industrial sector reports the highest productivity level, service sector displays a slightly lower productive, while agricultural sector considerably lags behind, appropriately affecting total economy's productivity level.

Statistical data indicate, that Lithuania generates the largest share of economy's value added $(7.1 \%$ in year 2002) among candidate countries, which all in their turn, could be evaluated as "overagriculturized" compared with EU-15 average, which equals only $2 \%$. To generalize, high share and low productivity of agricultural sector obviously is in detriment of Lithuanian economy total productivity compared to other accession countries.

The issue seems to be even more urgent, when share of employed in agriculture is considered. While employment in agriculture continued to decline, percentage of labor force engaged in agriculture remains in Lithuanian as high as 19.5\% in year 2002.

Tendencies of restructuring of transition country are being determined by several groups of factors, among which are objective, such as consistent patterns of development and subjective, as active state policy. In case of agricultural development, obviously, active participation of state is required. Diminishing of agricultural sector, both in output and employment terms, and increasing of its productivity are critical issues, which should be tackled actively, what, together with objective contraction tendencies, would underpin restructuring and economic growth of Lithuania.

Notably, that despite of such low labor productivity in agriculture Lithuanian's total labor productivity is increasing significantly: in 1993 it was $27.2 \% \mathrm{EU}$ level, while in 2003 it rose to $43.6 \%$ and has optimistic forecast to 2004 year (44.9\% of EU). The tendency could be even more optimistic, if efficient means towards agricultural sector were undertaken.

Another significant determinant of restructuring is foreign trade. Elaboration of its structure could help to reveal the efficient state policy towards restructuring of Lithuania.

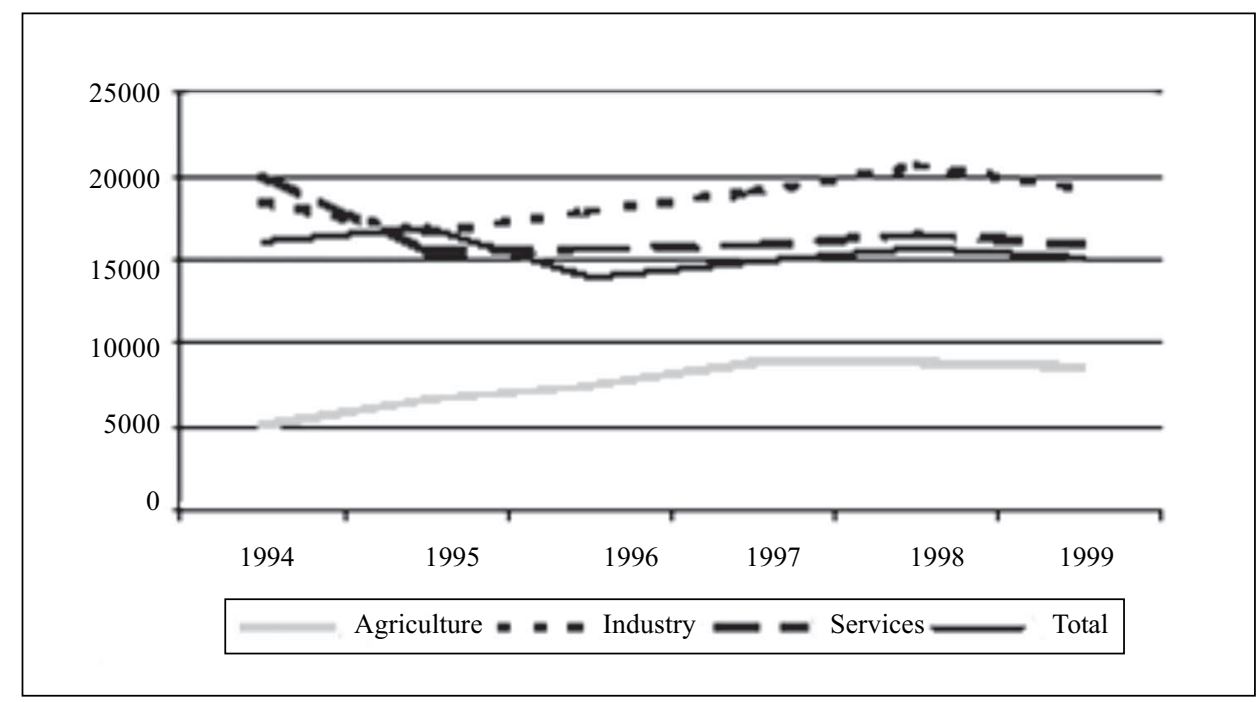

Chart 2. Productivity Levels by Main Economic Activity (in thousands of 1995 litas, productivity of contruction is omitted 


\section{Role of foreign trade and implications of EU accession}

There is an important issue that has received relatively little empirical literature, what is the causal relationship between foreign exports and state economic performance. The positive associations between foreign exports and state economic performance found in previous studies provide no indication of whether export growth is a driver of regional economic growth, or whether export growth is merely the consequence of strong state economic performance (Leichenko et al, 1999).

In our paper we assume, that economic structure of country is affected by foreign trade, especially by its export characteristics revealing prevailing comparative advantage of exporting country.

Each country strives to exceed its export. Alas, Lithuania experiences permanent trade deficit (Chart 3)

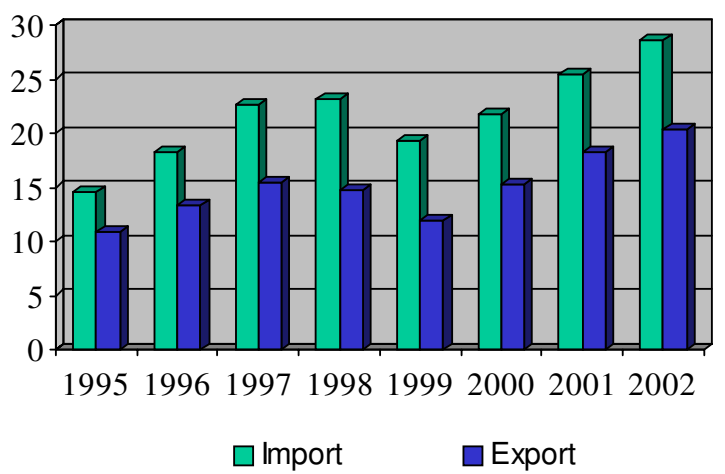

Chart 3. Lithuanian foreign trade - import and export, 1995-2002 (Lt Billion)
Import from CIS remains relatively unchanged, what signals about dependence of country on Russian raw materials

Exports initiate productivity growth; exporting firms outperform non-exporters in terms of productivity levels and changes. Closer look at share of total export by trade area indicates that during the last decade Lithuanian trade has undergone significant geographical reorientation. In 1998 crisis in Russia led to decline in exports to the region. Lithuania shifted its export towards EU markets with growing importance of manufactured goods in the countries total export basket. As part of this process, Lithuania has developed a growing specialization in unskilledlabor-intensive products, such as apparel, textiles or furniture (World Bank, (2002)).

Hence, close statistical look at economic and export structure reveals quite controversial situation: despite Lithuania enjoys high rates of economic growth, it is based on comparatively temporal advantage, i.e. low paid low-skilled labor force. Keeping in mind, that in long term prices, including prices of productive resources, converge, we can claim, that Lithuania in the quite near future can loose its comparative advantage, what, in its turn, most likely will affect its growth rates.

Current situation couldn't be positively evaluated. To sustain export growth, Lithuania has to reorient itself to skilled -labor and capital-intensive goods.

Table 1. FDI inflows 1997-2001

\begin{tabular}{|c|c|c|c|c|c|c|c|c|c|c|}
\hline & \multicolumn{2}{|c|}{1997} & \multicolumn{2}{|c|}{1998} & \multicolumn{2}{|c|}{1999} & \multicolumn{2}{|c|}{2000} & \multicolumn{2}{|c|}{2001} \\
\hline & Mo ECU & $\%$ of GDP & Mio ECU & $\%$ of GDP & Mo EUR & $\%$ of GDP & Mio EUR & $\%$ of GDP & Mo EUR & $\%$ of GDP \\
\hline Bulgaria & 445 & 4.9 & 479 & 4.2 & 723 & 5.9 & 1086 & 7.9 & 397 & 2.6 \\
\hline Cyprus & 433 & 5.8 & 237 & 2.9 & 642 & 7.4 & 872 & 9.1 & 728 & 7.1 \\
\hline Czech Rep. & 1148 & 2.5 & 2416 & 4.8 & 4792 & 9.3 & 5405 & 9.7 & 5489 & 8.7 \\
\hline Estonia & 235 & 5.8 & 513 & 11.0 & 284 & 5.8 & 425 & 7.6 & 603 & 9.8 \\
\hline Hungary & 1928 & 4.8 & 1815 & 4.3 & 1849 & 4.1 & 1837 & 3.6 & 2730 & 4.7 \\
\hline Lithuaria & 313 & 3.7 & 826 & 8.6 & 456 & 4.6 & 410 & 3.4 & 498 & 3.7 \\
\hline Latvia & 460 & 9.3 & 318 & 5.8 & 352 & 5.7 & 442 & 5.7 & 198 & 2.3 \\
\hline Malta & 71 & 2.4 & 238 & 7.6 & 830 & 24.3 & 674 & 17.5 & 350 & 8.7 \\
\hline Poland & 4328 & 3.4 & 5677 & 4.0 & 6821 & 4.7 & 10133 & 5.9 & 6377 & 3.2 \\
\hline Romania & 1071 & 3.4 & 1812 & 4.8 & 977 & 2.9 & 1110 & 2.8 & 1442 & 3.2 \\
\hline Slovenia & 414 & 2.6 & 178 & 1.0 & 78 & 0.4 & 149 & 0.8 & 562 & 2.7 \\
\hline Slovak Rep. & 154 & 0.8 & 504 & 26 & 306 & 1.6 & 318 & 1.5 & 1647 & 7.2 \\
\hline Turkey & 710 & 0.4 & 838 & 0.5 & 763 & 0.4 & 1063 & 0.5 & 3647 & 2.2 \\
\hline TOTAL & 11711 & 2.4 & 15852 & 3.0 & 18872 & 3.5 & 23925 & 3.8 & 24669 & 3.9 \\
\hline
\end{tabular}

Provisional data for 2001 . 


\section{Impact of Foreign direct investments (FDI) on national economy}

World Bank report outlines (World Bank, (2002)) that to sustain strong export growth in the medium term Lithuania will gradually have to improve its ability to export skilled-labor and/or capital-intensive goods. Recent developments in this regard, however, are not encouraging. Both categories of products experienced a decline in their export specialization indices between 1995 and 1999, and their combined share in total exports fell from 29 to 23 percent. Lithuania appears to be lagging behind many other Central and Eastern European countries in this area. In Poland, for example, the share of capital and skilled-labor intensive goods increased during a comparable period, from 31 percent of total exports to 45 percent (Eurostat). Lithuania also lags behind other accession countries in exports to markets with high growth potential, and in participation in international production and distribution networks. The slower progress of Lithuania in these areas can be largely attributed to lower inflows of FDI relative to other accession countries, and to the fact that they started the restructuring and trade reorientation process later than elsewhere and Lithuania has had a relatively low private investment to GDP ratios (Table 1).

If Lithuania manages to increase investment flows (both foreign and domestic) in the future, it is likely to experience a boost in exports of skilled-labor and capital-intensive goods similar to that experienced by Poland. The cause of this trend is an entrenching attitude that the ability of companies to compete on the international markets highly depends on the ability of the companies to use and develop the knowledge channeled partly through inflows of foreign capital.

\section{Quality of labor force}

In order to overcome historically large gaps in productivities of EU and transition countries, such as Lithuania, and, in short-term, be able to compete with high-skilled intensive European goods, appropriate policy towards improving skills of labor force should be undertaken.

In Table 2 level of spending on human resources for EU-15 and transition countries is presented. Despite Lithuania nears the average of EU-15, in percentage terms, real spending on education, measured in absolute figures remains rather low and not sufficient.

Evaluation of level of spending on research and development isn't straightforward. On the one hand, adequate $R \& D$ funding that is commensurate with economic growth as investment in intangible assets could be seen as a major source of productivity growth. On the other hand, the incentives to invest in R\&D are also tied to the size of the economy, whether that size is measured as the stock of human capital or the size of the labor force. Larger markets imply stronger incentives to conduct $\mathrm{R} \& \mathrm{D}$, which in turn leads to faster growth. (Braconier, Henric, (2000))

According to those statements, effectiveness' of R\&D expenditure depends not only on the amount, but also likewise on the size of market of the country. Second evidence, which a show how difficult is to evaluate

Table 2. Spending on human resources (public Expenditure on education as \% of GDP),Eurostat

\begin{tabular}{|l|c|c|c|c|c|c|c|c|c|c|}
\hline & $\mathbf{1 9 9 1}$ & $\mathbf{1 9 9 2}$ & $\mathbf{1 9 9 3}$ & $\mathbf{1 9 9 4}$ & $\mathbf{1 9 9 5}$ & $\mathbf{1 9 9 6}$ & $\mathbf{1 9 9 7}$ & $\mathbf{1 9 9 8}$ & $\mathbf{1 9 9 9}$ & $\mathbf{2 0 0 0}$ \\
\hline EU (15 countries) & $:$ & $:$ & $:$ & $:$ & $5,17^{(\mathrm{e})}$ & $5,18^{(\mathrm{e})}$ & $5,04^{(\mathrm{e})}$ & $5,05^{(\mathrm{e})}$ & $5,00^{(\mathrm{e})}$ & $4,94^{(\mathrm{e})}$ \\
\hline Euro-zone & $:$ & $:$ & $:$ & $:$ & $:$ & $:$ & $:$ & $:$ & $:$ & $:$ \\
\hline Bulgaria & $:$ & 5,28 & 5,05 & 4,21 & 3,36 & 2,58 & 2,64 & 3,23 & 3,66 & 4,41 \\
\hline Cyprus & $:$ & $:$ & 4,55 & 4,76 & 4,81 & 5,05 & 5,66 & 5,77 & 5,65 & 5,6 \\
\hline Czech Republic & $:$ & $:$ & 5,3 & 5,41 & 4,91 & 4,96 & 4,71 & 4,2 & 4,34 & 4,38 \\
\hline Estonia & $:$ & $:$ & 7,05 & 6,64 & 7,02 & 7,27 & 7,08 & 6,77 & 7,37 & 6,66 \\
\hline Hungary & $:$ & 6,46 & 6,28 & 6,13 & 5,04 & 4,48 & 4,61 & 4,56 & 4,66 & 4,54 \\
\hline Lithuania & $:$ & $:$ & 4,58 & 5,6 & 5,25 & 5,26 & 5,54 & 6,07 & 6,25 & 5,78 \\
\hline Latvia & $:$ & 4,55 & 6,07 & 6,12 & 6,95 & 5,79 & 5,66 & 6,83 & 6,28 & 5,86 \\
\hline Malta & $:$ & 4,71 & 5,01 & 4,95 & 4,99 & 5,3 & 5,48 & 5,21 & 5,1 & 4,91 \\
\hline Poland & $:$ & 5,37 & 5,37 & 4,92 & 5,5 & 5,05 & 5,17 & 5,42 & 5,18 & 5,06 \\
\hline Romania & $:$ & 3,47 & 3,02 & 3 & 3,32 & 3,55 & 3,24 & 4,38 & 3,37 & 2,89 \\
\hline Slovakia & $:$ & 5,98 & 4,72 & 3,9 & 4,98 & 4,5 & 4,8 & 4,51 & 4,4 & 4,15 \\
\hline Turkey & 3,32 & 3,73 & 3,74 & 2,87 & 2,38 & 2,57 & 2,92 & 3,24 & 3,8 & 3,49 \\
\hline
\end{tabular}


the effect and results of $R \& D$ expenditure, is discussed in new growth theory. It states, people devote resources to innovations in the pursuit of aboveaverage profit. The pace of innovation depends on the resources devoted to it. But profitable new discoveries are copied and replicated many times, so their benefits spread throughout the economy without diminishing returns. (Parkin (1996)). Statistical data, presented in Table 3 shows that input in researches and developments of new member countries, including Lithuania, in comparison with EU countries, is relatively small.

Nevertheless, talking about small countries, as Lithuania, we are tended to doubt, whether big investments in such field as research and development brought equivalent profit because of the small size of economy. It seems that better option is to absorb achievements and orient to prompt implementation of latter ones.

In the presented context, it is clear, that importance of spending on information technologies (IT) is beyond question for transition countries.

Statistical data presented in Table 4 refers, that IT expenditure indicator in Lithuania goes up for $0.1 \%$ every last four years. In 2003 it reached 1.9\% of GDP. Nevertheless, Lithuanian is obviously lagging behind and needs to undertake especially active policy in rapid implementation of IT, which could be treated as necessary condition of spillovers in field of research and development

Table 3. Researches and Experimental Development Expenditure as \% of GDP,Eurostat

\begin{tabular}{|l|c|c|c|c|c|c|c|c|c|c|c|}
\hline & $\mathbf{1 9 9 2}$ & $\mathbf{1 9 9 3}$ & $\mathbf{1 9 9 4}$ & $\mathbf{1 9 9 5}$ & $\mathbf{1 9 9 6}$ & $\mathbf{1 9 9 7}$ & $\mathbf{1 9 9 8}$ & $\mathbf{1 9 9 9}$ & $\mathbf{2 0 0 0}$ & $\mathbf{2 0 0 1}$ & $\mathbf{2 0 0 2}$ \\
\hline EU (15 countries) & 1,92 & 1,94 & 1,91 & 1,89 & 1,88 & 1,87 & 1,88 & 1,92 & 1,95 & 1,98 & 1,99 \\
\hline & $:$ & $:$ & $:$ & $:$ & $:$ & $:$ & $:$ & $:$ & $:$ & $:$ & $:$ \\
\hline Bulgaria & 1,64 & 1,18 & 0.88 & 0.62 & 0,52 & 0,51 & 0,57 & 0,57 & 0,52 & 0.47 & $:$ \\
\hline Cyprus & $:$ & $:$ & $:$ & $:$ & $:$ & $:$ & 0.23 & 0.25 & 0.25 & 0.27 & $:$ \\
\hline Czech Republic & $:$ & $:$ & $:$ & $:$ & $:$ & $:$ & $:$ & $:$ & 1,23 & 1,22 & $:$ \\
\hline Estonia & $:$ & $:$ & $:$ & $:$ & $:$ & $:$ & 0.61 & 0.75 & 0.66 & 0.78 & $:$ \\
\hline Hungary & 1,05 & 0.98 & 0.89 & 0.73 & 0.65 & 0.72 & 0.68 & 0.69 & 0.80 & 0.95 & $:$ \\
\hline Lithuania & $:$ & $:$ & 0.52 & 0.46 & 0,52 & 0.56 & 0.56 & 0.52 & 0.60 & 0.69 & $:$ \\
\hline Latvia & 0.59 & 0.49 & 0.42 & 0.53 & 0.47 & 0.42 & 0.45 & 0.40 & 0.48 & 0.44 & $:$ \\
\hline Poland & $:$ & $:$ & $:$ & $:$ & $:$ & $:$ & $:$ & 0.70 & 0.66 & 0.64 & 0.59 \\
\hline Romania & $:$ & $:$ & $:$ & $:$ & $:$ & $:$ & $:$ & 0.40 & 0.37 & 0.39 & $:$ \\
\hline Slovenia & 1,91 & 1,6 & 1,76 & 1,61 & 1,36 & 1,35 & 1,4 & 1,44 & 1,46 & 1,57 & $:$ \\
\hline Slovakia & $:$ & $:$ & 0.90 & 0.93 & 0.92 & 38231 & 0.79 & 0.66 & 0.65 & 0.64 & 0.58 \\
\hline Turkey & 0.49 & 0.44 & 0.36 & 0.38 & 0.45 & 0.49 & 0.50 & 0.63 & 0.64 & $:$ & $:$ \\
\hline
\end{tabular}

Table 4. IT Expenditure as \% of GDP,Eurostat

\begin{tabular}{|l|c|c|c|c|}
\hline & $\mathbf{2 0 0 0}$ & $\mathbf{2 0 0 1}$ & $\mathbf{2 0 0 2}$ & $\mathbf{2 0 0 3}$ \\
\hline EU (15 ountries) & 3,3 & 3,2 & 3 & 3 \\
\hline Euro-zone & 3 & 2,9 & 2,7 & 2,7 \\
\hline Bulgaria & 1,9 & 1,9 & 1,9 & 2 \\
\hline Czech Republic & 3,3 & 3,4 & 3,7 & 3,8 \\
\hline Estonia & 3,7 & 3,5 & 3,5 & 3,4 \\
\hline Hungary & 3,2 & 3,1 & 2,9 & 2,9 \\
\hline Lithuania & 1,6 & 1,7 & 1,8 & 1,9 \\
\hline Latvia & 2,4 & 2,4 & 2,5 & 2,4 \\
\hline Poland & 1,8 & 1,9 & 1,9 & 2,2 \\
\hline Romania & 1,5 & 1,3 & 1,2 & 1,1 \\
\hline Slovenia & 2,2 & 2,1 & 2,1 & 2,1 \\
\hline Slovakia & 2,6 & 2,8 & 2,9 & 2,8 \\
\hline Turkey & 3,4 & 1,3 & 1 & 0,8 \\
\hline
\end{tabular}




\section{Conclusions}

Structure of Lithuanian GDP indicates that services and industry are main sectors of economics. Despite agricultures share is declining, it still remains comparatively high and, in Lithuanian case, plays extremely important role in economy.

Lithuanian industrial sector reports the highest productivity level, service sector displays a slightly lower productive, while agricultural sector considerably lags behind, appropriately affecting total economy's productivity level. Diminishing of agricultural sector, both in output and employment term, and increasing of its productivity are critical issues, which should be tackled actively, what, together with objective contraction tendencies, would underpin restructuring and economic growth of Lithuania.

Lithuania, having trade of $92.4 \%$ of GDP could be treated as rather open if compared to EU member countries (EU-15 average equals $73.7 \%$ ); alas, Lithuania experiences permanent trade deficit. The main characteristic of import is, that during transition years CIS prevail and the tendency relatively unchanged, what signals about dependence of country on Russian raw materials. Lithuania shifted its export towards EU markets with growing importance of manufactured goods in the countries total export basket. As part of this process, Lithuania has developed a growing specialization in unskilled-laborintensive products, such as apparel, textiles or furniture.

Current situation couldn't be positively evaluated. To sustain export growth, Lithuania has to reorient itself to skilled -labor and capital-intensive goods.

Taking into consideration implications of accession on foreign trade and agricultural sector, the following outcomes for Lithuanian economy could be expected: i) exports even more oriented towards EU with increase of competitive pressure on domestic firms; ii) imports will become more expensive, what finally could increase production costs; iii) rates of contraction of agricultural sector would be accelerated by decreased demand for local goods.

Hence, implications of EU accession requires to undertake active state policy aimed to enhancing of export potential and trough reorientation to skilledlabor and capital-intensive goods.

The common agreement is that exports initiate productivity growth; exporting firms outperform nonexporters in terms of productivity levels and changes.
Analysis of FDI flows into Lithuania revealed Lithuania has more exploit this factor in the future.

Necessity to compete with high-skilled intensive European goods in short-term requires appropriate policy towards improving skills of labor force. Despite Lithuania nears the average of EU-15, in percentage terms, real spending on education, measured in absolute figures remains rather low and not sufficient. Evaluation of level of spending on research and development isn't so straightforward.

\section{References}

1. Braconier, H. Do Higher Per Capita Incomes Lead to More R\&D Expenditure? Review of Development Economics, 2000, p. 244-257.

2. Leichenko R. M., Coulson N. E. Foreign Industrial Exports and State Manufacturing Performance. Growth and Change 30, 1999, p. 479-506.

3. Parkin, M. Economics. Third edition, University of Weatern Ontario, 1996. $603 \mathrm{p}$.

4. Raiser M., Schaffer M., Schuchardt J. Benchmarking structural change in transition. Structural Change and Economic Dynamics, Volume 15, Issue 1, March 2004, p. $47-81$.

5. A World Bank Study. Lithuania: Country Economic Memorandum. Converging to Europe: Policies to Support Employment and Productivity Growth. Volume I: Main Report. June 17, 2002

6. Eurostat. http://europa.eu.int/eurostat/-European Commission database. Observed in 2004. 03. 22 